\title{
Perception of Learning Management System Among Distance Learners in South-West, Nigeria
}

\author{
Esther M. Ajijola, Gboyega Ayodeji Aladesusi *, Oyeronke Olufunmilola Ogunlade, \\ Charles O. Olumorin \\ Department of Educational Technology, Faculty of Education, University of Ilorin, 240103 Ilorin, Nigeria \\ *Corresponding author: aladesusigboyega@gmail.com
}

Received: 20 June 2021; Accepted: 6 August 2021; Published: 23 August 2021

\begin{abstract}
Learning Management System (LMS) is a common platform where students and teachers can interact digitally, most especially in Open and Distance Learning (ODL) institutions. However, it has been discovered over time that most of the distance learners with poor study habits lag behind in its utilization. The purpose of this study was to investigate the Perception of Learning Management System among Distance Learners' in South-West, Nigeria. Emphasis was on gender and field of study using an adapted Technology Acceptance Model (TAM). This study employed a descriptive research method. Data were collected through the administration of a-validated researcher-adapted questionnaire. Descriptive statistics of mean and standard deviation were used to answer research questions one and two. Inferential statistics of t-test and ANOVA were used to test the hypotheses at 0.05 level of significance. The research findings indicated that there were significant differences between male and female distance learners in their: perceived usefulness of LMS $(p=0.00)$; perceived ease of use of LMS $(p=0.004)$; in favour of males; there was no significant difference among Sciences, Arts and Social Science distance learners on their perceived usefulness and perceived ease of use of LMS. It was therefore recommended that training and support programs be established to ensure a sustainable use and prevent collapse of LMS in the institutions in respective of distance learners' gender and field of study.
\end{abstract}

Keywords: Learning Management System, Perceived Usefulness, Perceived Ease of Use, Distance Learners, Gender and Field of Study

\section{INTRODUCTION}

One significant innovative technology to expand teaching and learning in $21^{\text {st }}$ century mostly in Distance Education, is e-learning. E-learning involves the delivery of information through the internet (Santy \& Smith, 2007). It involves learning with the aid of ICTtechnology but not yet a full substitute for traditional method of learning (Behera, 2013). In this $21^{\text {st }}$ century, e-learning has experienced monumental growth as some institutions have separate online campus in addition to the existing face-to-face campus. E-learning includes the use of software, internet, CD-ROM, online learning or any other electronic or interactive media to disseminate information (Nagarajan \& Wiselin, 2010). All students and tutors could add and contribute to the learning activities from any geographical location, and a variety of educational opportunities can be constantly shared and retrieved. Through e-learning, both lecturers and students benefit from streamline learning process using Open-Source Learning Management System (LMS) because of its low cost of application with many features and attainment (Ololube, 2014; Syamsuddin \& Alimin, 2014). 
LMS is known in literature by several names, including course management system, virtual learning environments and e-learning courseware (Moore, et al., 2011). The LMS helps students and lecturers by facilitating alternative way to learn, communicate and save time as well as making e-learning content easier to be accessed, (Munasinghe \& Wojewardana, 2017). LMS is defined as an online digital environment that allows information to be shared between tutor and students and providing access to content and administrative features for specific courses within an integrated environment (White \& Larusson, 2010). LMS is also a comprehensive system that streamlines an organization's needs for both its clients and its employees (Obadara, 2014). Obadara also opined that organizations using LMS have a central place to store course material online for access by specified users. LMS usage serves as a medium to stimulate pedagogical process by blending traditional learning practice and online learning environments (Alghamdi \& Bayaga, 2016).

LMS uses variety of tools and functions such as course management tools, online group chat and discussion, homework collections and grading, documentation, course evaluation tracking, and reporting of course or classroom events between various people that participate. Moodle is an example of such LMSs. MOODLE, that is Modular Object-Oriented Dynamic Learning Environment was established at Curtin University in Western Australia by Martin Dougiamas (Kennedy, 2005; Smart \& Cappel, 2006; Singh, et al., 2010). Moodle comprises features which can be understood from the six classified main factors, they are: Course and Curriculum Design, Administrator Tools and Instructor Tools (Momani, 2010). However, it is obvious that the expectation of distance learners towards the use of LMS has now increased anxieties for such concern in certain parts of the country for example, in Southwest, Nigeria. For relevance of LMS within an education context, undergraduates' perceived usefulness, perceived ease of use, attitude and utilization of LMS must be investigated. A person who finds a technology useful will use more of the technology as compared to another person who finds it not useful. (Ibrahim, et al., 2011).

Perception is a feeling taken after experience through the interpretation of stimulus recorded in the brain by more than one sense organ. What one perceives may be different from what others perceive; that is individual have different perception of things (Okron \& Koko, 2009). According to Venkatesh and Davis (1996) and Pin and Hsin-Hui (2005) perception can be grouped into perceived usefulness (the extent to which a person believes that using technology will improve his/her routine) and perceived ease of use, (is when a person believes that using technology will be free of exertion). Successful adoption of new technology depends on user's attitude towards and acceptance of such technology (Davis, et al., 1989).

Researches on Learning management system has a great contribution to the fields of education which has contributes to an understanding of information behaviors leading to effective learning. To measure the efficiency and effectiveness of using LMS, users' perception is reckoned as an essential parameter of success and failure. The acceptance of LMS is based on the perception of its users and when users have a negative perception it can result to low usage leading to destroying many organizational investments in information technology (Karahanna, et al., 1999; Venkatesh \& Davis, 2000). It was suggested that connecting perception with actual use is not easy as opined by Hanson and Robson (2004) in a study in which they examined the use of two commercial LMS (WebCT and Blackboard). In their finding it was evident that the students reported that these systems improved their learning.

Liyanagunawardena (2008), indicated that no significant relationship between the perception students had about the LMS and it actual use. Almarashdeh, et al. (2010) indicates that the ability of LMS to allow student and instructors to accomplish his learning task, enhance effectiveness in learning and increase learning efficiency is more significant than easy to access information, easy to use and clear interaction of the LMS. The study also confirms that the reception of the LMS is vital in determining whether the system is working and used by students and instructors in Malaysian universities. Trayek and Hassan (2013) also examined 
the perceptions of students at the Defence University on the use of the LMS. Result showed that users had a positive attitude towards the use of the LMS. Nevertheless, that there are some technical issues that must be addressed to certify that the LMS can function excellently. None of the aforementioned study revealed whether there is positive or negative attitude of students towards the use of LMS in an open and Distance Learning.

In respect to technology utilization several researches have been conducted to examine factors influencing the use or application of technology. These factors serve as barrier to the effective utilization of technology among faculty member. These are gender, field of study and age among others (Mahmud, 2006; Venkatesh \& Morris, 2000). Gender gap issue has held many researchers' attention and as a result, numerous studies have been conducted to study this gap in ICT. Gender issues is very paramount in all aspects of the society to the extent that access of woman to certain occupation and abilities in higher institution is affected by gender variance. Studies had proven that females tend to be minus involved in computer and use them less often in their spare time (Schaumburg, 2001).

Okron and Koko (2009) in their study examines the students' perception of National Open University of Nigeria scheme using Calabar study centre as a case study concluded that there was no gender difference. Also, Tayo (2015) observed that male pre-service teachers have a better perception of LMS than female pre-service teachers. In India, Suri and Sharm (2013) also affirm that no gender difference exists in students' attitudes towards e-learning. Sisay (2018) concluded that there is no difference between male and female students' perception towards technology utilization. However, to the best knowledge and materials available to the researcher, studies on gender imbalance towards using technology for learning remained inconclusive as further study is required. However, taking all the literature reviewed here into account it cannot be conclude from the studies that there is regularity in Internet use irrespective of student course of study.

A Learning Management System (LMS) is an online digital environment that provides a comprehensive set of tools for both tutor and students to interact together. Some instructors opined that because of evolving Web 2.0 applications, students can be better served by an LMS alternative which makes learning content easily accessible and managed. In addition, it helps instructors to provide their students with learning materials and manage student registration, a toolbox of web resources that might include social bookmarking tools, document sharing applications and social networking (Obadara, 2014; EDUCAUSE, 2010; Okron \& Koko, 2009).

However, it has been discovered over time that most of the distance learners are not motivated, those with poor study habits lag behind in it utilization, some courses can be difficult to simulate, instructors may not be available at the expected time and there may be epilithic Internet connectivity. Obadara (2014) noted that to come to terms with these complexities, it is essential for learners to embrace the use of LMS for better academic performance at any level of education. And success of any technology integration into instructional process depends highly on users' acceptance of the system rather than the system itself. In Nigeria, not much research has been conducted in relation to LMS usage most especially in distance education (single mode Universities) in South-west Nigeria. It is on this note that this study examines Perception of Learning Management System Among Distance Learners' in South-west, Nigeria, focusing on some moderating variables of gender and field of study. Specifically, the study; determined distance learner's perception on the usefulness of LMS, investigated distance learner's perception on the ease of use of LMS, examined the significant difference between male and female distance learners' perceived usefulness of LMS, investigated the significant difference between male and female distance learners' perceived ease of use of LMS, investigated the influence of distance learners' field of study on their perceived usefulness of LMS, examined the influence of distance learners' field of study on their perceived ease of use of LMS. 


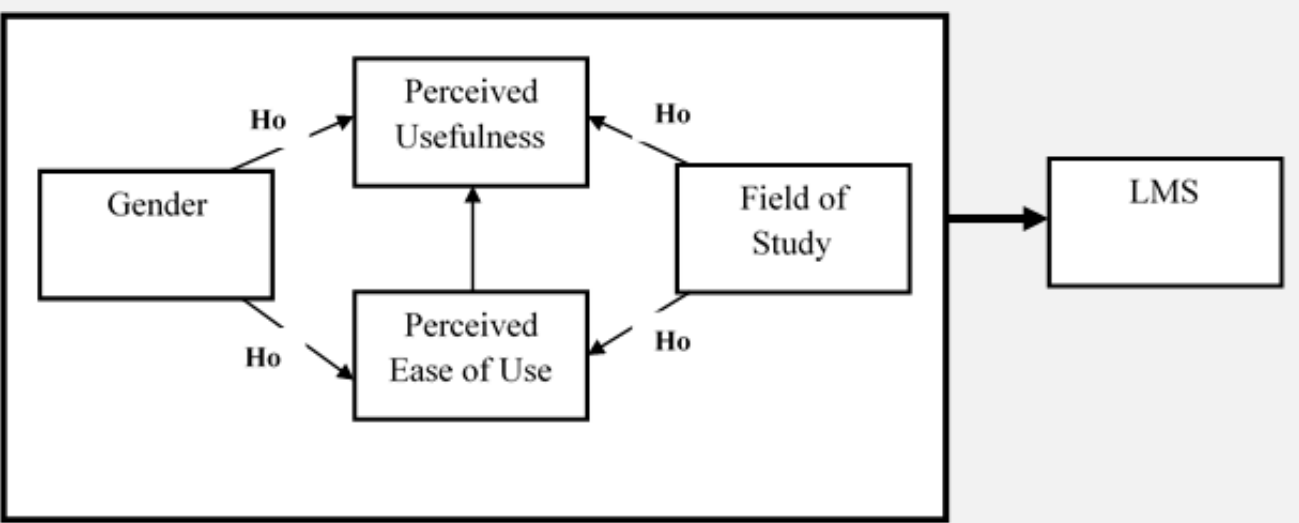

Figure 1. The Hypothesized Model on Perceived Usefulness and Perceived Ease of Use of Learning Management System among Distance Learners'

\section{METHOD}

\section{Research Design}

The study adopted descriptive research of survey method. Descriptive research of survey method was chosen for the study because it enables the researcher to gather a large amount of information on distance learners' perception, attitude and utilization of Learning Management System thought the use of questionnaire.

\section{Population, Sample and Sampling Techniques}

The population for the study were all distance learners (single and dual mode) in Universities in South-west, Nigeria with a total number of 46,848 . The target population for the study consisted of all Distance Learners in single mode Universities in South-west Nigeria. Learners from each of the study centres (Akure, Osogbo, Ado-Ekiti, Abeokuta, Ikeja and Ibadan) of National Open University of Nigeria were sampled. Purposive sampling technique was used to select all the six study centres in South-west, Nigeria because they all converge at the state capitals for their examinations. Sample size model by Israel (1992) was used to select distance learners from each of the distance learning institutions in South-west in the study after the census of all the distance learners had been taken while stratified sampling technique was used to stratify respondents along gender and field of study.

Table 1. List of Selected Universities in South-west, Undergraduates' Population and Proportional Samples for the Study at $\pm 7 \%$ using Israel (1992) Model of determining sample size

\begin{tabular}{clcc}
\hline No & Name of Institutions & $\begin{array}{c}\text { Undergraduates } \\
\text { population }\end{array}$ & $\begin{array}{c}\text { Proportional } \\
\text { sample size }\end{array}$ \\
\hline 1 & NOUN Abeokuta Study Centre & 6,850 & 198 \\
2 & NOUN Ado-Ekiti Study Centre & 4,326 & 196 \\
3 & NOUN Akure Study Centre & 6,580 & 198 \\
4 & NOUN Ibadan Study Centre & 10,654 & 201 \\
5 & NOUN Ikeja Study Centre & 10,980 & 201 \\
6 & NOUN Osogbo Study Centre & 7,458 & 199 \\
\hline \multicolumn{4}{c}{ Total } \\
\hline
\end{tabular}

Source: Academic Unit of the Universities

Table 1 revealed the population of distance learners in the institutions which was 46,848 , out of which $\pm 7 \%$ of the total population from each institution was sampled at $93 \%$ confidence interval. Thus, the total number of respondents sampled were 1,193. 


\section{Research Instruments}

The research instruments used for the study were questionnaire and inspection guide which included a checklist of the available learning resources in the Universities. An adapted questionnaire from Govender, et al. (2014); Baleghi-Zadeh, et al. (2014); Lonn, et al. (2009) were used to obtain information from the respondents. Items were selected based on their relevance to perceived usefulness and perceived ease of use of LMS. An inspection guide adapted from Fasakin (2017) was used by the researcher to gather information on the available learning resources in the Universities. While the questionnaire contained two major sections, Sections I and II. Section I focused on respondents' biographical information such as institution, gender and field of study. Section II was sub-divided into two (A and B). These sub-divisions are:

A. Undergraduates' perceived usefulness of LMS.

B. Undergraduates' perceived ease of use of LMS.

Each of these sub-divisions contained 10 items numbered 1-10, making a total of 40 items.

\section{Data Analysis Techniques}

The analysis and interpretation of data obtained were done using descriptive and inferential statistics. Frequencies, mean, standard deviation and bar chart was used to analyze the research questions. Hypothesis 1 and 2 were tested using independent $t$-test while hypotheses 3 and 4 were tested using ANOVA. All hypotheses were tested at 0.05 level of significance.

\section{RESULT AND DISCUSSION}

\section{Demographic Information of Respondent}

Demographic status of respondents by gender was presented in Table 2. It showed that respondents of male gender were 299 with $42.9 \%$ while 398 (57.1\%) were female. Figure 2 present bar chart of respondent by gender.

Table 2. Percentage Distribution of Respondents by Gender

\begin{tabular}{lcc}
\hline Gender & No of Respondents & Percentage \\
\hline Male & 299 & 42.9 \\
Female & 398 & 57.1 \\
Total & 697 & 100.0 \\
\hline
\end{tabular}

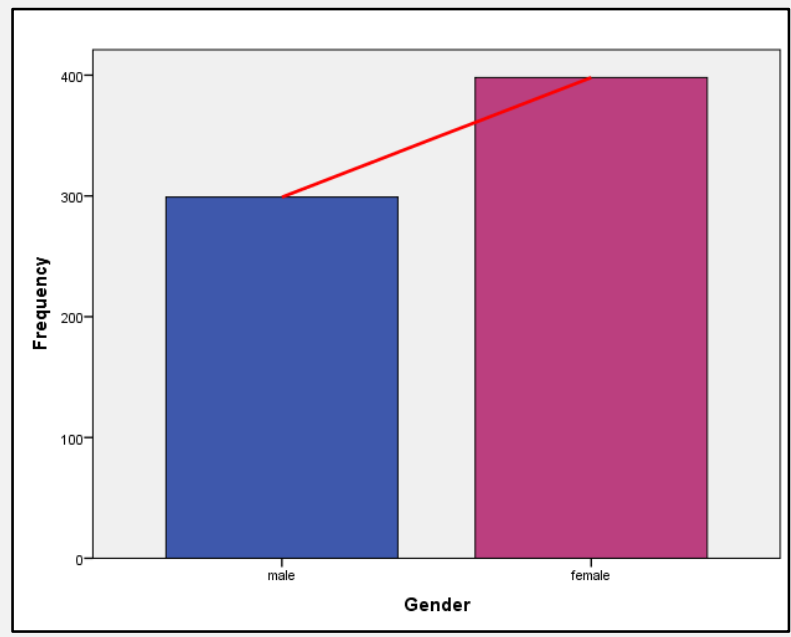

Figure 2. Respondent by Gender 
The bar showed that female has the highest bar more than their male respondents. Thus, the field of study of respondents need to be reviewed. This was analysed in Table 3.

Table 3. Percentage Distribution of respondents by Field of Study

\begin{tabular}{lcc}
\hline Field of study & No of Respondents & Percentage \\
\hline Science & 284 & 40.7 \\
Arts & 149 & 21.4 \\
Social Science & 264 & 37.9 \\
Total & 697 & 100.0 \\
\hline
\end{tabular}

Table 3 represents the demographic status of respondents by their field of study. It was revealed from table 2 that majority of the respondents in Sciences were $284(40.7 \%)$ Arts were 149 (21.4\%) while Social Sciences were 264 (37.9\%). A chart better presents the illustration of respondents based on their field of study as shown in Figure 3.

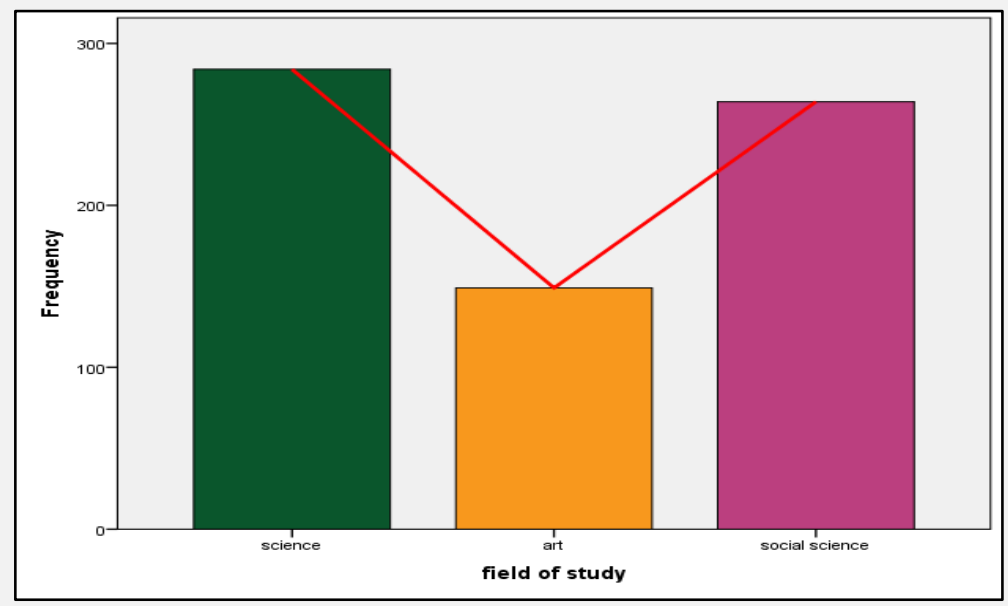

Figure 3. Respondents Based on Their Field of Study

Figure 3 present bar chart of respondents by their field of study. The bar showed that science respondents had the highest bar more than arts and social science respondents.

\section{Analysis of Research Questions}

This part presents the result of the analyses on perceived usefulness and perceived ease of use of learning management system among distance learners.

Research Question 1:

What is the perception of distance learners on the usefulness of LMS?

The researcher analyzed the responses from the items on the questionnaire and the results were as shown in Table 4 that revealed that using LMS improved distance leaners' academic achievement was ranked highest having the mean score 3.26 out of maximum of 4 . This was followed by LMS gives more control over learning, using LMS calendar was more useful when finding out about events, LMS helps to learn more efficiently, LMS system makes learning more effective and LMS has a positive effect on learning having the mean scores of $3.20,3.15,3.14,3.11,3.11$ and 3.10 respectively. The lowest mean scores were 3.07, 3.06 and 2.87 with the statement that said I find LMS useful when discussing topic of studies with classmates, the LMS makes learning more meaningful and through LMS I find it useful to 
communicate to with teachers and friends. However, the grand mean score for perception of distance learners on the usefulness of LMS was found to be 3.12 using 2.0 as the bench-mark. It can then be inferred that distance learners' perceived usefulness of LMS was positive.

Table 4. Perceived usefulness of LMS

\begin{tabular}{clcc}
\hline No & \multicolumn{1}{c}{ Statements } & Mean & $\begin{array}{c}\text { Std. } \\
\text { Dev }\end{array}$ \\
\hline 1 & Using LMS improves my academic achievement & 3.26 & 0.68 \\
2 & I find using LMS calendar more useful when finding out about events & 3.14 & 0.67 \\
3 & LMS gives me more control over my learning & 3.15 & 0.68 \\
4 & LMS helps me learn more efficiently & 3.11 & 0.72 \\
5 & LMS system makes my learning more effective & 3.11 & 0.70 \\
6 & LMS has a positive effect on my learning & 3.10 & 0.73 \\
7 & Through LMS I find it useful to communicate to my teachers and & 2.87 & 0.86 \\
& friends. & 3.06 & 0.73 \\
8 & The LMS makes learning more meaningful & 3.07 & 0.78 \\
9 & I find LMS useful when discussing topic of my studies with my & & \\
& classmates & 3.20 & 0.73 \\
10 & LMS is useful when downloading course materials uploaded by my & & \\
\hline & lecturers. & 3.12 & 0.47 \\
\hline
\end{tabular}

Research Question 2:

What is the perception of distance learners on the ease of use of LMS?

The researcher analyzed the responses from the items on the questionnaire and the results were as shown in Table 5.

Table 5. Perceived Ease of Use of LMS

\begin{tabular}{clll}
\hline No & \multicolumn{1}{c}{ Statements } & Mean & Std. Dev \\
\hline 1 & I quickly understand the LMS process & 3.13 & 0.73 \\
2 & It is easy for me to become skillful in ICT when using LMS & 3.14 & 0.76 \\
3 & LMS is easy to handle problem whenever I encounter & 2.95 & 0.80 \\
& them & & \\
4 & $\begin{array}{l}\text { My interaction with LMS as a student does not require me } \\
\text { to seek for assistance }\end{array}$ & 2.89 & 0.83 \\
5 & Learning through LMS is easy for me & 3.05 & 0.76 \\
6 & It is easy to get relevant materials from LMS & 3.10 & 0.74 \\
7 & I find it easy to download course materials uploaded by & 3.15 & 0.73 \\
& my lecturers when using LMS & 3.00 & 0.79 \\
8 & LMS makes it easier for me to comprehend & 2.77 & 0.87 \\
9 & The LMS makes it more convenient to communicate with & 2.86 & 0.82 \\
\hline & my lectures & 3.01 & 0.49 \\
\hline
\end{tabular}

It could be noted from Table 5 that participants find it easy to download course materials uploaded by lecturers when using LMS was ranked highest having the mean score 3.15 out of maximum of 4 . This was followed by it is easy for to become skillful in ICT when using LMS, I quickly understand the LMS process, it is easy to get relevant materials from LMS, learning through LMS is easy and LMS makes it easier to comprehend having the mean scores of $3.14,3.13,3.10,3.05$ and 3.00 respectively. The lowest mean scores were 2.95, 2.89, 2.86 
and 2.77 with the statement that LMS is easy to handle problem whenever you encounter them, interaction with LMS as a student does not require me to seek for assistance, I find it easy to take quizzes when using LMS and LMS makes it more convenient to communicate with lectures. However, the grand mean score for perception of distance learners on the usefulness of LMS was found to be 3.01 using 2.0 as the average bench-mark. It can then be inferred that distance learners' perceived usefulness of LMS was positive.

\section{Hypotheses Testing}

Hypothesis One

$H_{O I}$ : There is no significant difference between male and female distance learners on their perceived usefulness of LMS.

Table 6: T-test Summary for Significant Difference Between Male and Female Distance Learners Perceived Usefulness of LMS

\begin{tabular}{lccccccc}
\hline Gender & No & Mean & $\begin{array}{c}\text { Std. } \\
\text { Deviation }\end{array}$ & Df & t & $\begin{array}{c}\text { Sig. } \\
\text { (2 tailed) }\end{array}$ & Remarks \\
\hline Male & 299 & 3.18 & .44 & 695 & 3.68 & .00 & Sig. \\
Female & 398 & 3.05 & .48 & & & & \\
\hline Total & 697 & & & & & & \\
\hline
\end{tabular}

The significant difference between male and female distance leaners' perceived usefulness of LMS was revealed in Table 6. The result showed that $t(695)=3.68, p<0.05$. the null hypothesis was rejected. This was because the result of the t-value of 3.68 resulting in 0.00 significance value was less than 0.05 alpha value. This implies that the null hypothesis which stated there was no significant difference between male and female distance learners on their perceived usefulness of LMS was rejected. It can therefore be concluded that there was significant difference between male and female distance learners on their perceived usefulness of LMS.

\section{Hypothesis Two}

$H_{O 2}$ : There is no significant difference between male and female distance learners on their perceived ease of use of LMS.

Table 7. T-test Summary for Significant Difference Between Male and Female Distance Learners Perceived Ease of Use of LMS

\begin{tabular}{lccccccc}
\hline Gender & No & Mean & $\begin{array}{c}\text { Std. } \\
\text { Deviation }\end{array}$ & Df & t & $\begin{array}{c}\text { Sig. } \\
(2 \text { tailed })\end{array}$ & Remarks \\
\hline Male & 299 & 3.07 & .47 & 695 & 2.89 & .004 & Sig. \\
Female & 398 & 2.95 & .52 & 69 & & & \\
\hline Total & 697 & & & & & & \\
\hline
\end{tabular}

Table 7 presents the result on significant difference between male and female distance learners on their perceived ease of use of LMS. The result showed that, $t(695)=2.89$, $p<0.05$. the null hypothesis was rejected. This was because the result of the t-value of 2.89 resulting in 0.004 significance value was less than 0.05 alpha value. This implies that the null hypothesis, there is no significant difference between male and female distance learners on their perceived ease of use of LMS was rejected. It can therefore be concluded that there was significant difference between male and female distance learners on their perceived ease of use of LMS. 
Hypothesis Three

$H_{O 3}:$ There is no significant difference among Sciences, Arts and Social Science distance learners on their perceived usefulness of LMS.

Table 8. ANOVA Summary for Significant Difference among Sciences, Arts and Social Science Distance Learners Perceived Usefulness of LMS

\begin{tabular}{lcccccc}
\hline & Sum of square & Df & Means square & F & Sig. & Remarks \\
\hline Between groups & .086 & 2 & .043 & \multirow{2}{*}{198} & \multirow{2}{*}{.821} & \multirow{2}{*}{ Not Sig. } \\
Within groups & 151.151 & 694 & .218 & & & \\
\hline Total & 151.237 & 696 & & & & \\
\hline
\end{tabular}

Table 8 revealed that there was no significant difference among Sciences, Arts and Social Sciences distance learners on their perceived usefulness of LMS. F $(2,694)=.198, p$ $=.821$. This therefore meant that the null hypothesis was not rejected because the significant value (.821) was greater than the 0.05 alpha level. By implication, the null hypothesis was established, thus, no significant difference existed among Sciences, Arts and Social Science distance learners on their perceived usefulness of LMS.

\section{Hypothesis Four}

$H_{O 4}$ : There is no significant difference among Sciences, Arts and Social Science distance learners on their perceived ease of use of LMS.

Table 9. ANOVA Summary for Significant Difference among Sciences, Arts and Social Science Distance Learners Perceived Ease of Use of LMS

\begin{tabular}{lcccccc}
\hline & Sum of square & Df & Means square & F & Sig. & Remarks \\
\hline Between groups & .503 & 2 & .252 & \multirow{2}{*}{1.015} & \multirow{2}{*}{.363} & \multirow{2}{*}{ Not Sig. } \\
Within groups & 172.123 & 694 & .248 & & & \\
\hline Total & 172.626 & 696 & & & & \\
\hline
\end{tabular}

Table 9 revealed that there was no significant difference among Sciences, Arts and Social Science distance learners on their perceived ease of use of LMS. F $(2,694)=1.015, p$ $=.363$. This therefore meant that the null hypothesis was not rejected because the significant value (.363) was greater than the 0.05 alpha level. By implication, the null hypothesis was established thus, no significant difference existed among Sciences, Arts and Social Science distance learners on their perceived ease of use of LMS.

\section{Discussions of Findings}

This paper has made an attempt to revealed that the perception of distance learners on the usefulness and ease of use of LMS was positive. The findings indicated that there was a positive response to all the statements for relative advantage. The finding was in support of Sisay (2018) who reported that students had positive perception toward technology assisted. Furthermore, the influence of distance learners' gender on their perceived usefulness and perceived ease of use of LMS was examined. The result of the $t$-test established that there existed significant difference between male and female distance learners on their perceived usefulness and perceived ease of use of LMS. These findings on gender influence agreed with findings of Olivia (2009) who reported that male uses the internet than their female counterpart in the use of ICT which institute a form of digital divide. The findings also agreed with the previous findings of India, Suri and Sharm (2013) whose findings affirm that no gender difference exists in students' attitudes towards e-learning. Sisay (2018) concluded that there is no difference between male and female students' perception towards technology utilization. However, these findings contradict the previous findings of Omotunde (2015) 
whose findings observed that male pre-service teachers have a better perception of LMS than female pre-service teachers.

Finally, on distance field of study, the result established that there was no significant difference among Sciences, Arts and Social Science distance learners on their perceived usefulness and perceived ease of use of LMS. This showed that students' field of study may affect their ICT facilitated technologies such as LMS. The findings of this study is inconsistent with the previous study of Tayo (2015) whose study posited that pre-service teachers in Chemistry department have a very good perception of the use of LMS while, History department have a relatively little/skimpy insight on the use of LMS. The present study also contradicts the previous study of Sriram (2014) whose study showed that students of Information Technology specialization had greater impact in using internet resources for learning when equated to others at undergraduate levels.

\section{CONCLUSION}

The study concluded that there is significant difference between male and female distance learners on their perceived usefulness and perceived ease of use of LMS. Thus, no significant difference existed among Sciences, Arts and Social Science distance learners on their perceived usefulness perceived ease of use of LMS. Based on the findings and conclusion of this study, the study recommends that; training and support programs be established to ensure a sustainable use and prevent collapse of LMS in the institutions in respective of distance learners' gender and field of study, the administrators for distance learning should provide free use of LMS resources most especially internet facilities for distance learners. This will make learning easy and more accessible to them, ODL institutions should encourage the use of LMS by providing useful content and improving internet service quality to all distance learners, efforts should be made to ensure that distance learners do not just have a positive perception but should be taught on the value of LMS to ensure effective utilization and It is also recommended that training and support programs be established to ensure a sustainable use and prevent collapse of LMS in the institutions in respective of distancer learners' gender and field of study.

\section{REFERENCES}

Alghamdi, S. R. \& Bayaga, A. (2016). Use and Attitude Towards Learning Management System (LMS) in Saudi Arabian Universities. Eurasia Journal of Mathematics \& Technology Education, 12(9)2309-2330. https://doi.org/10.12973/eurasia.2016.1281a

Almarashdeh, I. A., Sahari, N., Zin, N. A. \& Alsmadi. M. (2010). The success of Learning Management System among distance learners in Malaysian universities. Journal of Theoretical and Applied Information Technology, 2 (2). Retrieved from: http://www.jatit.org/volumes/research-papers/Vol21No2/2Vol21No2.pdf

Baleghi-Zadeh, S., Ayub, A. F. M., Mahmud, R., \& Daud, S. M. (2014). Behavior intention to use of learning management system among Malaysian pre-service teachers: A confirmatory factor analysis. International Journal of Education and Literacy Studies, 2(1), 29-39.

Behera, S. K. (2013). E- and m-learning: A comparative study. International Journal on New Trends in Education and their Implications, 4(3)65-78.

Davis, F. D., Bagozzi, R. P. \& Warshaw, P. R. (1989). User acceptance of computer technology: A comparison of two theoretical models. Management Science, 35(8), 982-1003. https://doi.org/10.1287/mnsc.35.8.982 
Dhindsa, H. S., \& Shahrizal-Emran (2011). Using interactive whiteboard technology-rich constructivist learning environment to minimize gender differences in chemistry achievement. International Journal of Environmental \& Science Education, 6(4), 393 414.

EDUCAUSE (2010). Things you should know about LMS alternatives. Retreived from https://net.educause.edu/ir/library/pdf/ELI7062.pdf

Govender, D. W., \& Dhurup, M. (2014). Perceptions of learners of a learning management system to support teaching and learning using the diffusion of innovation theory. Mediterranean Journal of Social Sciences, 5(8), 377. http://dx.doi.org/10.5901/mjss.2014.v5n8p377

Hanson, P., \& Robson, R. (2004). Evaluating course management technology: A pilot study. Boulder, CO: EDUCAUSE Centre for Applied Research, Research Bulletin, Issue 24.

Ibrahim, A. A., Noraidah, S., Nor Azan, M., \& Mutasem, A. (2011). Acceptance of Learning Management System: A Comparison between Distance Learners and Instructors. Advanced in Information Sciences and Service Sciences, 3(5), 1-9

Karahanna, E., Staub, D. W., \& Chervany, N. L. (1999). Information technology adoption across time: A cross sectional comparison of pre-adoption and post-adoption beliefs. MIS Quarterly, 23(2), 183-213. https://doi.org/10.2307/249751

Kennedy, D. M. (2005). Challenges in evaluating Hong Kong students' perceptions of Moodle. In The Australasian Society for Computers in Learning in Tertiary Education Conference (ASCILITE 2005) (pp. 327-336).

Liyanagunawardena, T. R. (2008). Measuring student perception and actual usage of online learning management system. Communications of the IBIMA, 4(21), 165-168.

Lonn, S., Teasley, S., \& Krumm, A. (2009). Investigating undergraduates' perceptions and use of a learning management system: A tale of two campuses. In Annual Meeting of the American Educational Research Association (April 16th), San Diego, California. Retrieved June (Vol. 6, p. 2014).

Mahmud, R. (2006). ICT Readiness Among Secondary School Teachers. Doctoral Dissertation, Universiti Kebangsaan Malaysia.

Momani, A. M. (2010). Comparison between two learning management systems: Moodle and blackboard. Retrieved from ERIC database UMM. http://www.eric.ed.gov.eserv.uum.edu.my/PDFS/ED509728.pdf.

Moore, J. L., Dickson-Deane, C. \& Galyen, K., 2011. e-Learning, online learning, and distance learning environments: Are they the same?. The Internet and Higher Education, 14(2), 29-135. https://doi.org/10.1016/j.iheduc.2010.10.001

Munasinghe, P. G. \& Wojewardana, W. P. (2017). Attitude of Student when using Learning Management systems.

Nagarajan, P. \& Wiselin J. G. (2010). Online educational system (e- learning). International Journal of u- and e-Service, Science and Technology, 3(4), 37-48 
Obadara, O. E. (2014). Effect of Learning Management System (LMS) on Students' Academic Performance in University of Lagos, Nigeria. International Journal of Educational Foundations and Management, 2(1), 25-33. Retrieved from http://www.ijefm.com

Okron, O. \& Koko, E. (2009). Students' Perception of the National Open University of Nigeria Scheme: A Case Study of Calabar Centre. African Research Review, 3(2), 347 35 .

Olivia, A. T. (2009). Comparing knowledge and usage of ICT among male and female distance learners of an endowed and deprived area in a developing country in Africa. Journal of information Technology Education, 8, 1-17.

Ololube, N. P. (2014). Blended learning methods in introduction to teaching and sociology of education courses at a university of education. In Advancing technology and educational development through blended learning in emerging economies (pp. 108127). IGI Global. https://doi.org/10.4018/978-1-4666-4574-5.ch006

Pin, L., \& Hsin-Hui, L. (2005). Toward an understanding of the behavioral intention to use mobile banking. Computers in Human Behavior, 873- 891. https://doi.org/10.1016/j.chb.2004.03.003

Pšunder, M. \&Virtič M. P. (2010). The influence of the field of study on the use of modern Information and Communication Technologies among student and teachers. Informatologia, 43 (4), 269-279.

Research and Markets. (2018, January 10). Nasdaq. Retrieved from https://g/obenewswire.com/new-release

Santy, J. \& Smith, L. (2007). Being an E-learner in health and social care : a student's guide, London: Routledge.

Schaumburg, H. (2001). Fostering girls' computer through laptop learning - Can mobile computers help to level out the gender difference? Retrieved from http://goo.gl/dWEClc

Singh, A., Mangalaraj, G., \& Tanrja, A. (2010). Bolstering teaching through online tools. Journal of Information Systems Education, 21(3), 215-229.

Sisay, A. W. (2018). University students' perception and utilization of technology for learning: The case of Haramaya University. International Journal of Pedagogy, Policy and ICT in Education, 6(1),17-32.

Sriram, B. (2014). Specialization Impact on Internet Resource Usage: Omani Undergraduate Learner's Perspectives. International Journal of Modern Education and Computer Science, 6(8), 10. https://doi.org/10.5815/ijmecs.2014.08.02

Smart, K. L. \& Cappel, J. J. (2006). Students' perceptions of online learning: A comparative study. Journal of Information Technology Education, 5, 201-219.

Suri, G., \& Sharma, S. (2013). The impact of gender on attitude towards computer technology and e-learning: An exploratory study of Punjab University, India. International Journal of Engineering Research, 2(2), 132-136. 
Syamsuddin, I. \& Alimin (2014). Assessing Moodle as Learning Management System Platform for English Course Based TOEFL. International Journal of Computer Trends and Technology (IJCTT), 18(6), 276-279.

Tayo, O. C. (2015). Pre-Service Teachers' Perception towards Integration of Learning Management System to Instruction. Global Journal of HUMAN-SOCIAL SCIENCE: $H$ Interdisciplinary, 15(17).

Trayek, F. A. A. \& Hassan, S.S.S. (2013). Attitude towards the use of Learning Management System Among University Students: A Case Study. Turkish Online Journal of Distance Education-TOJDE, 14(3), 91-103.

Venkatesh, V., \& Davis, F. D. (2000). A theoretical extension of the technology acceptance model: Four longitudinal field studies. Management Science, 46, 186-204. https://doi.org/10.1287/mnsc.46.2.186.11926

White, B. \& Larusson J. A. (2010). Strategic Directives for Learning Management System Planning. ECAR Research Bulletin, 21.

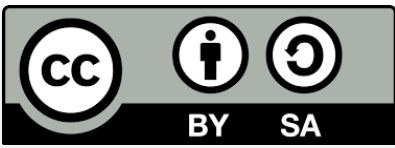

Copyright (c) 2021 by the authors. This work is licensed under a Creative Commons Attribution-ShareAlike 4.0 International License. 